\title{
PEMBERDAYAAN KADER POSYANDU DALAM PROMOSI KELUARGA BERENCANA DAN KONTRASEPSI
}

\section{(EMPOWERMENT OF POSYANDU CADRES IN PROMOTION OF FAMILY PLANNING AND CONTRACEPTION)}

\author{
Ni Ketut Alit Armini ${ }^{1}$, Mira Triharini ${ }^{2}$, Aria Aulia Nastiti ${ }^{3}$ \\ ${ }^{1,2,3}$ Fakultas Keperawatan Universitas Airlangga \\ e-mail: nk.alita@fkp.unair.ac.id
}

\begin{abstract}
One of the efforts to empower the community in the health sector is to develop Posyandu. The role of posyandu cadres in the promotion of family planning and contraception programs in couples of childbearing age is still limited. This activity aims to improve the ability of cadres in promoting family planning and contraception. The activity was carried out for 4 weeks in the Bringkang village area, Menganti District, Gresik Regency, namely on 3-28 July 2018. The method of activities was in the form of socialization, posyandu cadre training with lectures, questions and answers, discussions (CTJD), and assistance in the implementation of posyandu. Average knowledge $(x=9.2)$ in the good category and cadre attitude $(x=13.1)$ in the positive category in the promotion of family planning and contraception. It is important to empower Posyandu cadres in health promotion, especially family planning and contraception in the community.
\end{abstract}

Keywords: cadres, contraception , empowerment, family

abstrak

Salah satu upaya pemberdayaan masyarakat di bidang kesehatan adalah menumbuhkembangkan posyandu. Peran kader posyandu dalam promosi program keluarga berencana dan kontrasepsi pada pasangan usia subur masih terbatas. Kegiatan ini bertujuan meningkatkan kemampuan kader dalam mempromosikan keluarga berencana dan kontrasepsi. Kegiatan dilaksanakan selama 4 minggu di wilayah desa Bringkang Kecamatan Menganti Kabupaten Gresik yaitu pada tanggal 3-28 Juli 2018. Metode kegiatan berupa sosialisasi, pelatihan kader posyandu dengan ceramah, tanya jawab, diskusi (CTJD), dan pendampingan pada pelaksanaan posyandu. Rerata pengetahuan $(\mathrm{x}=9,2)$ dalam kategori baik dan sikap kader $(\mathrm{x}=13,1)$ kategori positif dalam promosi KB dan kontrasepsi. Penting memberdayakan kader posyandu dalam promosi kesehatan khususnya KB dan kontrasepsi di masyarakat.

Kata kunci: kader, keluarga, kontrasepsi, pemberdayaan

\section{PENDAHULUAN}

Kecenderungan penggunaan kontrasepsi dalam program Keluarga Berencana (KB) di Indonesia belum berbasis pada pertimbangan rasionalitas, efektivitas dan efisiensi (BKKBN, 2013; Hartanto, 2008). Rendahnya penggunaan MKJP, minimnya akseptor IUD dan meningkatnya pengguna pil dan suntik serta animo yang tinggi terhadap implant merupakan salah satu bukti kesertaan masyarakat ber-KB belum dipertimbangkan dengan baik. Peminat alat dan obat kontrasepsi dengan masa efektivitas pendek semakin meningkat, maka biaya yang harus dikeluarkan untuk penyediaan kontrasepsi tinggi(Badan Pusat Statistik, 2012; Manuaba, 2009). 
Di Jawa Timur akseptor KB IUD yang terdaftar pada tahun 2015 sebagai akseptor KB baru sebanyak 5.742 dari jumlah 83.148 akseptor. Jumlah Pasangan Usia Subur (PUS) di Jawa Timur sebanyak 7.846.174 jiwa (BKKBN, 2015). Angka penggunaan Metode Kontrasepsi Jangka Panjang (MKJP) cenderung menurun dari 10,9\% menjadi 10,6\%. Pasangan Usia Subur (PUS) di Kabupaten Gresik tahun 2014 sebesar 259.451 akseptor, yang menjadi peserta KB baru 19.366 akseptor (7,5\%) dan sebagai peserta KB aktif 181.014 akseptor (69,8\%). Pada tahun 2013 sebesar 235.636 akseptor sedangkan yang menjadi peserta KB baru 29.707 akseptor (13\%) dan sebagai peserta KB aktif 170.288 akseptor (72\%). Intensitas banyaknya peserta $\mathrm{KB}$ baru dan $\mathrm{KB}$ aktif mengalami penurunan, seiring dengan semakin bertambahnya jumlah PUS di Kabupaten Gresik. Indikasi kurangnya tingkat kepedulian dari Pasangan Usia Subur terhadap pentingnya Keluarga Berencana dalam keteraturan berumah tangga.

Pemberdayaan masyarakat desa Bringkang yang termasuk wilayah Kecamatan Menganti Kabupaten Gresik dengan promosi Keluarga Berencana dan Kontrasepsi masih perlu dilakukan. Desa Bringkang dengan luas wilayah 3,43 km. Populasi penduduk desa Bringkang 5.077 jiwa dengan jumlah Kepala Keluarga (KK) sebanyak $1.462 \mathrm{KK}$. Berdasarkan data survey kesehatan keluarga yang dilakukan mahasiswa KKN BBM Unair ke 56 pengguna alat kontrasepsi sebanyak 61 dari 119 KK (51,3\%) jauh dari target sasaran akseptor Kabupaten Gresik. Kurangnya partisipasi masyarakat dalam program KB dan penggunaan kontrasepsi dapat menimbulkan masalah kesehatan pada ibu dan anak, serta mempengaruhi kondisi sosial dan kesejahteraan keluarga. Promosi dan penyuluhan tentang keluarga berencana dan pelayanan kontrasepsi masih terbatas dilakukan oleh kader di posyandu. Kegiatan Posyandu masih terbatas pada penimbangan berat badan balita, dan pemberian makanan tambahan. Perlu penguatan potensi Kader di desa Beringkang dalam promosi program keluarga berencana dan kontrasepsi.

Program KB dapat meningkatkan status kesehatan wanita dan menyelamatkan kehidupannya (BKKBN, 2008). Apabila tidak melakukan kontrasepsi KB akan timbul kekhawatiran terhadap terjadinya kehamilan yang tidak diinginkan, gangguan fisik psikologi akibat tindakan abortus yang tidak aman, serta tuntutan perkembangan sosial terhadap peningkatan status perempuan di masyarakat (Kementrian Kesehatan RI, 2012)

KB seharusnya menjadi salah satu program prioritas, karena merupakan investasi yang menguntungkan. Semua pihak harus dapat menyadari, dampak program KB tidak dapat dirasakan hasilnya dalam waktu singkat. Pelayanan program KB mampu mengendalikan pertumbuhan penduduk dan meningkatkan kualitas keluarga. Pembangunan yang berwawasan penduduk adalah model pembangunan yang bertujuan untuk memperluas peluang agar penduduk dapat hidup layak, yaitu dalam keadaan sehat dan berumur panjang, berpendidikan cukup, dan berkecukupan pula secara ekonomi.

\section{METODE PENGABDIAN MASYARAKAT}

Kegiatan melibatkan khalayak sasaran kader posyandu di wilayah Desa Bringkang untuk berperan aktif. Kegiatan dilaksanakan bekerjasama dengan Perangkat Desa, Bidan, dan 10 orang mahasiswa Universitas Airlangga lintas Fakultas yang sedang melaksanakan kegiatan Kuliah Kerja Nyata Belajar Bersama Masyarakat ke 58 di wilayah Desa Bringkang yaitu pada tanggal 3-28 Juli 2018. 
Pelaksanaan kegiatan mencakup beberapa 2 (dua) tahap meliputi: Tahap pertama sosialisasi kegiatan, curah pendapat, penyuluhan dan penyegaran informasi materi Peran Kader, KB dan kontrasepsi berupa ceramah, diskusi, tanya jawab dilaksanakan di ruang kelas Taman Kanak- Kanak, samping Balai Desa Bringkang. Tahap kedua pendampingan dan monitoring evaluasi kader oleh tim pelaksana bekerjasama dengan mahasiswa KKN-BBM mensosialisasikan KB dan Kontrasepsi kepada ibu yang membawa balitanya dalam pelaksanaan posyandu.

\section{HASIL DAN PEMBAHASAN}

Tabel 1 : Karakteristik Peserta Kader Posyandu Desa Bringkang 2018 (n=20)

\begin{tabular}{llcc}
\hline Karakteristik & Kategori & f & \% \\
\hline Usia & 20-35 tahun & 6 & 30 \\
& 36-50 tahun & 10 & 50 \\
& $>50$ tahun & 4 & 20 \\
Pendidikan & SD SMP SMA & 2 & 10 \\
& Perguruan Tinggi & 4 & 20 \\
& & 12 & 60 \\
Pekerjaan & & 2 & 10 \\
& IRT & 15 & 75 \\
Lama Sbg Kader & Berdagang Swasta & 3 & 15 \\
& & 2 & 10 \\
Pengalaman Pelatihan & 3 & 15 \\
& 2-3 tahun & 6 & 30 \\
& Belum Pernah ASI \& Gizi & 11 & 55 \\
& Bayi Kejang & 10 & 50 \\
& Kesehatan Ibu Hamil & 6 & 30 \\
& Bahaya merokok & 1 & 5 \\
& & 1 & 5 \\
& & 2 & 10 \\
\hline
\end{tabular}

\section{Tahap Pertama}

Informasi Sebelum Kegiatan Promosi KB dan Kontrasepsi Pengetahuan kader posyandu tentang tugasnya di masyarakat yakni: membantu bidan dalam kegiatan posyandu, meningkatkan kesehatan ibu hamil dan balita, mengajak masyarakat hidup sehat, mencatat data ibu hamil, balita, dan lansia, menimbang balita di Posyandu.

Wawasan Kader tentang program KB \& Kontrasepsi di wilayah Desa Bringkang meliputi: KB dilayani di Bidan terdekat, kehamilan dan kelahiran dikendalikan dengan keluarga berencana, KB bagi ibu-ibu dan warga sangat bermanfaat, pelaksanaannya masih kurang, takut efek lainnya, warga di sekitar lingkungan kurang berminat berKB.

Penyampaikan informasi dan promosi tentang KB dan Kontrasepsi dengan CTJD 
(Ceramah, Tanya Jawab, Diskusi) tentang : peran dan fungsi kader, pelayanan Keluarga Berencana $(\mathrm{KB})$, jenis kontrasepsi, pertimbangan pemilihan kontrasepsi.

\section{Informasi Sesudah Kegiatan Promosi KB dan Kontrasepsi}

Evaluasi kegiatan penyuluhan dan penyegaran materi KB dan kontrasepsi pada kader posyandu dilaksanakan dengan memberikan kuesioner post test yang terdiri dari pernyataan Benar-Salah untuk mengukur pengetahuan dan pernyataan dengan skala likert untuk mengukur sikap kader tentang peran kader dan pelayanan $\mathrm{KB}$, kontrasepsi. Diidentifikasi tingkat pengetahuan kader seluruhnya dalam kategori baik dengan rerata score 9,2. Sikap kader dalam upaya promosi KB dan kontrasepsi seluruhnya dalam kategori positif dengan rerata skore 13,1 .

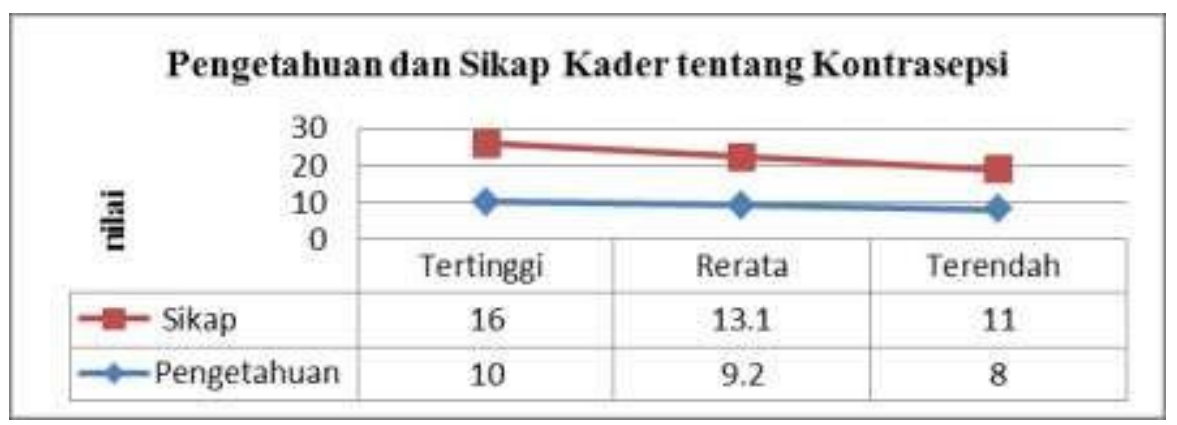

Gambar 1: Nilai post test tingkat pengetahuan dan sikap kader posyandu di wilayah Desa Bringkang 2018

Komitmen Kader Posyandu dalam Promosi KB dan Kontrasepsi Setelah penyuluhan dan penyegaran dengan metode CTJD (Ceramah, Tanya Jawab, Diskusi)

Berikut kutipan jawaban peserta :

"Mendatangi pasangan usia subur untuk mengikuti KB" "Mengenalkan macam-macam KB pada PUS" "Memberi penyuluhan KB dengan benar" "Menyampaikan informasi tentang KB ke warga sekitar kader" "Memberi pengetahuan kepada masyarakat tentang manfaat KB"

\section{Tahap Kedua}

Promosi KB dan Kontrasepsi dilaksanakan oleh Kader dalam kegiatan posyandu didampingi oleh mahasiswa yang melaksanakan KKN BBM di wilayah Desa Bringkang Kecamatan Menganti Kabupaten Gresik. Ibu-ibu kader mencoba menerapkan materi penyegaran kader yang diberikan khususnya memberikan penyuluhan $\mathrm{KB}$ dan kontrasepsi dengan media leaflet yang difasilitasi tim pelaksana pengabdian masyarakat. Berdasarkan informasi kader sebelumnya terbiasa melakukan kegiatan posyandu rutin khususnya mencatat data Balita yang datang, menimbang, dan memberikan makanan tambahan. Masyarakat yang datang ke posyandu, terburu melakukan kegiatan lain, sehingga penyuluhan kesehatan termasuk tentang $\mathrm{KB}$ dan kontrasepsi tidak dilakukan secara khusus. 
Kader yang hadir pada saat pelatihan dan penyegaran pelayanan keluarga berencana dan kontrasepsi mengetahui tugasnya di masyarakat sangat penting untuk mengajak masyarakat hidup sehat. Pelayanan kader difokuskan pada upaya meningkatkan kesehatan ibu hamil dan balita. Sesuai penelitian Nursalam; Dinna Agustina;Ni Ketut Alit Armini (2010) pengetahuan kader tentang perannya dipengaruhi pengalaman kader dan pelatihan yang pernah didapatkan. Terdapat 11 orang yang telah melaksanakan tugas sebagai kader > 3 tahun, bahkan informasi lisan yang disampaikan ada yang telah mengabdi sekitar 20 tahun. Rutinitas dalam pelaksanaan tugas kader di posyandu mempengaruhi persepsi kader tentang peran dan fungsinya. Kesempatan pelatihan dan penyegaran kader masih terbatas, sebanyak 50\% kader belum pernah mengikuti pelatihan kader. Sebagian lainnya pernah mendapatkan pelatihan ASI dan gizi (30\%), bayi kejang (5\%), kesehatan ibu hamil (5\%), dan bahaya merokok (10\%). Identifikasi awal pengetahuan dan sikap kader tentang perannya dan situasi program KB dan kontrasepsi didapatkan sebagian besar memahami perannya sangat penting untuk mendukung peningkatan kesehatan di lingkungan masyarakat, dan menyadari terkait pelayanan KB dan kontrasepsi masih perlu ditingkatkan.

Setelah kegiatan pengabdian masyarakat dengan Ceramah, Tanya Jawab, dan Diskusi (CTJD) hasil evaluasi dengan post test didapatkan nilai rerata tingkat pengetahuan kader 9,2 dan nilai rerata sikap 13,1. Nilai tersebut menunjukkan pengetahuan kader tentang KB dan kontrasepsi pada kategori baik, dan sikap kader positif terhadap upaya promosi KB dan kontrasepsi.

Menurut Notoatmojo (2007), pengalaman adalah salah satu faktor eksternal yang dapat mempengaruhi seseorang. Pengalaman seorang individu bisa diperoleh dari lingkungan maupun proses perkembangan. Semua kader yang bertugas dan mengikuti kegiatan pemberdayaan berusia $>20$ tahun. Kategori usia dewasa mempengaruhi kematangan mental dan kemampuan bertanggung jawab secara soaial pada lingkungan. Selain pengalaman, tingkatan pendidikan menjadi salah satu faktor yang mempengaruhi tingkat pengetahuan seseorang. Pendidikan seseorang akan berpengaruh dalam memberikan respon terhadap sesuatu yang datang dari luar. Sebagian besar kader berpendidikan SMA, meskipun ada 2 orang kader yang berpendidikan SD namun kader tersebut telah berpengalaman lama melaksanakan tugas sebagai kader, mengawali terbentuknya kader posyandu di desa Bringkang. Menurut Notoatmojo (2007) peningkatan pengetahuan seseorang tidak mutlak diperoleh di pendidikan formal saja tetapi juga dapat diperoleh melalui pendidikan informal. Pengetahuan seseorang dapat dipengaruhi oleh banyak faktor, antara lain faktor internal dan faktor eksternal. Faktor internal berupa jasmani dan rohani seseorang. Faktor eksternal sendiri dapat berupa pendidikan, paparan media massa, ekonomi, hubungan sosial serta pengalaman.

Ada 11 orang (55\%) telah melaknakan tugas sebagai kader lebih dari 3 tahun, bahkan ada satu orang yang menyampaikan sudah bertugas sekitar 20 tahun. Berdasarkan pengamatan tim pelaksana pengmas, setelah mengikuti penyuluhan dan penyegaran, kader lebih antusias dalam kegiatan posyandu tidak hanya melakukan pencatatan,penimbangan balita yang datang, tetapi juga mampu memotivasi untuk masyarakat mengikuti program KB.

Keputusan sebagai akseptor $\mathrm{KB}$ sangat erat hubungannya dengan informasi dan 
pengetahuan yang dimiliki, dengan pengetahuan maka orang akan semakin luas pula wawasannya (BKKBN, 2008, 2013). Perlu ditekankan, bukan berarti seseorang yang berpendidikan rendah mutlak berpengetahuan rendah. Pengetahuan tidak hanya bisa didapatkan melalui pendidikan formal, tapi juga bisa melalui media yang lain misalnya penyuluhan(Priyoto, 2014). Sebagian besar wanita pasangan usia subur mendapatkan informasi KB dan kontrasepsi dari petugas kesehatan dan kader. Peran kader sangat penting dalam mempromosikan pelayanan keluarga berencana, untuk meningkatkan motivasi dan sikap masyarakat dalam pelayanan KB (Ramdhani, 2010; Yacobson, Christopherson, \& Michaelides, 2012). Pembentukan sikap tidak terjadi dengan sendirinya, tetapi pembentukan senantiasa berlangsung dalam interaksi manusia dan berkenaan dengan alternatif yaitu senang atau tidak senang, mendukung atau tidak mendukung, menjauhi atau mendekati (Sciortino, 1998). Sikap diikuti atau tidak diikuti oleh suatu tindakan berdasarkan banyak atau sedikitnya pengalaman seseorang (Fatmah, 2013). Pembentukan sikap seseorang dipengaruhi oleh pengalaman pribadi, pengaruh orang lain yang dianggap penting, media massa, institusi atau lembaga pendidikan dan lembaga keagamaan serta faktor emosi pada diri individu(Hayden J, 2009; Notoatmojo, 2007). Termasuk dalam sikap memanfaatkan pelayanan KB dan kontrasepsi yang berhubungan dengan aspek kependudukan.

Masalah kependudukan penting dalam pembangunan, tidak hanya dilihat dari sisi kuantitas, tetapi juga berkaitan dengan masalah kualitas dan mobilitas (BKKBN, 2008). Sesuai amanat undang- undang Nomor 52 Tahun 2009 tentang Perkembangan Kependudukan dan Pembangunan Keluarga, penduduk harus menjadi titik sentral dalam pembangunan berkelanjutan di Indonesia.

\section{PENUTUP}

\section{Simpulan dan Saran}

Pengetahuan dan sikap kader tentang KB dan kontrasepsi pada kategori baik setelah mendapatkan program pengabdian masyarakat dengan CTJD dan pendampingan. Ketrampilan dan kepercayaan diri kader dalam mempromosikan KB dan kontrasepsi meningkat setelah mendapatkan program pengabdian masyarakat. Kader posyandu perlu diberdayakan dalam promosi program keluarga berencana dan kontrasepsi, sebagai ujung tombak untuk meningkatkan kesehatan masyarakat.

\section{DAFTAR PUSTAKA}

Badan Pusat Statistik. 2012. Survei Demografi dan Kesehatan Indonesia. Jakarta. BKKBN. 2008. Peningkatan Akses dan Kualitas Pelayanan KB. Bandung.

BKKBN. 2013. Pemantauan Pasangan Usia Subur Melalui Mini Survey Indonesia. Jakarta.

BKKBN. 2015. Rencana Strategis Badan Kependudukan dan Keluarga Berencana Nasional Tahun 2015-2019. Jakarta.

Fatmah. 2013. Pengaruh Pelatihan pada Peningkatan Pengetahuan dan Keterampilan Teknis Penyuluhan Obesitas dan Hipertensi Kader Posbindu Kota Depok. Makara Seri Kesehatan, 17(2), 49-54. 
Hartanto, H. 2008. Keluarga Berencana dan Kontrasepsi. Jakarta: Pustaka Sinar Harapan.

Hayden J. 2009. Introduction to health behaviour theory. USA: Jones and Bartlett Publisher.

Kementrian Kesehatan RI. 2012. Survey Demografi dan Kesehatan Indonesia. Jakarta. Retrieved from www.chnrl.org

Manuaba, I. A. C. 2009. Memahami Kesehatan Reproduksi Wanita. Jakarta: EGC.

Notoatmojo, S. 2007. Promosi Kesehatan dan Ilmu Perilaku. Jakarta: Rineka Cipta.

Nursalam; Dinna Agustina;Ni Ketut Alit Armini. 2010. "Training of Growth Record Changes a Behaviour for Posyandu's Cadres”. Jurnal Ners, 5(1), 70-78.

Priyoto. 2014. Teori Sikap dan Perilaku dalam Kesehatan. Yogyakarta: Nuha Medika. Ramdhani, A. (2010). Women's Health. Leaf Production.

Sciortino, R. 1998. "The Challenge of Addressing Gender In Reproductive Health Programmes Examples From Indonesia”. Reproductive Health Matter, 6(11), 33-44. Retrieved from http://dx.doi.org/10.1016/50968-8080(98)90080-5

Yacobson, I., Christopherson, K., \& Michaelides, T. 2012. Facts For Family Planning. Baltimore: USAID. 